\title{
Diagnosis dan Penatalaksanaan Fraktur Le Fort I-II disertai Fraktur Palatoalveolar Sederhana
}

\author{
Dewi Yuri Lestari ${ }^{1}$, Al Hafiz², Effy Huriyati²
}

\begin{abstract}
Abstrak
Pendahuluan: Fraktur pada sepertiga tengah wajah (midface) memerlukan pemeriksaan yang teliti dan penatalaksanaan yang tepat. Fraktur palatoalveolar jarang terjadi dan dapat terjadi bersamaan dengan fraktur lain pada trauma wajah. Pada beberapa dekade terakhir, berbagai modalitas penatalaksanaan fraktur sepertiga tengah wajah telah dicoba. Penatalaksanaan fraktur sepertiga tengah wajah dengan menggunakan fiksasi dengan miniplate dan screw mengungguli teknik-teknik terdahulu. Laporan Kasus: Dilaporkan satu kasus fraktur Le fort I-II dan fraktur palatoalveolar sederhana pada seorang laki-laki umur 19 tahun. Telah dilakukan Open Reduction Internal Fixation (ORIF) dengan miniplate dan screw serta pemasangan wire. Simpulan: ORIF dengan miniplate dan screw telah menjadi pilihan pada fraktur maksilofasial karena lebih stabil dalam hal fungsi dan fiksasi tulang yang lebih baik. Berdasarkan indikasi, fiksasi intermaksila, palatum splint, dan wire dapat digunakan secara tersendiri atau kombinasi untuk penatalaksanaan fraktur palatoalveolar.
\end{abstract}

Kata kunci: Fraktur maksilofasial, Le Fort I, Le Fort II, ORIF, fraktur palatoalveolar

\begin{abstract}
Introduction: Fractures of the middle third of the face require careful examination and expectant management skills. Palatoalveolar fracture was rare, with another facial skeleton Through the decades, several modalities of management of midface fractures have been tried. The avenue in the management of midface trauma, in the form of fixation with miniplates and screws, which surpassed all the shortcomings of the previous technique. Case report: Reported a case Le Fort I-II and palatoalveolar fracture. Has been done Open Reduction Internal Fixation (ORIF) with miniplate and screw. Conclusion: ORIF with miniplate and screw has been choice in maxillofacial fracture management because can stabilize and fixation well. Based on indication, intermaxillary fixation, palate splint and wire can be used it self or with combination for management palatoalveolar fracture.
\end{abstract}

Keywords: Maxillofacial fracture, Le fort I, Le Fort II, ORIF, palatoalveolar fracture

Affiliasi penulis : Bagian Telinga Hidung Tenggorok (THT) FK Unand Padang/ RSUP dr. M. Djamil

Korespondensi : 1. Bagian THT-KL FK Unand. 2. Bagian THT-KL FK Unand. Jl. Perintis kemerdekaan no. 94 PO BOX 49 Padang 25127, email: dewi.hadziq@gmail.com

\section{PENDAHULUAN}

Fraktur pada sepertiga tengah tulang wajah sering terjadi dan merupakan trauma yang membahayakan. Fraktur pada bagian ini memerlukan pemeriksaan yang teliti dan penatalaksanaan yang tepat. ${ }^{1}$ Pada tahun 1901, Le Fort melaporkan tentang trauma tumpul yang dilakukan pada tengkorak kadaver yang diberikan berbagai besar kekuatan dan berbagai arah trauma. Fraktur cenderung terjadi pada lokasi tertentu, yang berhubungan dengan wilayahwilayah yang lemah pada skeleton wajah. Le Fort menyimpulkan adanya alur yang dapat diprediksi mengikuti tipe dari arah trauma. ${ }^{2}$ Fraktur sepertiga tengah tulang wajah lainnya sering terjadi berhubungan dengan fraktur Le Fort, termasuk fraktur palatoalveolar dan mandibula yang memberikan pengaruh pada oklusal dan berpengaruh pula pada penatalaksanaannya. ${ }^{3}$

Anatomi maksilofasial

Sepertiga tengah dari skeleton wajah (Gambar 1) terdiri dari 2 os maksila, 2 os zigoma, 2 prosesus zigoma dari os temporal, 2 os palatine, 2 os lakrimal, vomer, etmoid yang berlengketan dengan konka, pterigoid plate dari sfenoid. ${ }^{4}$

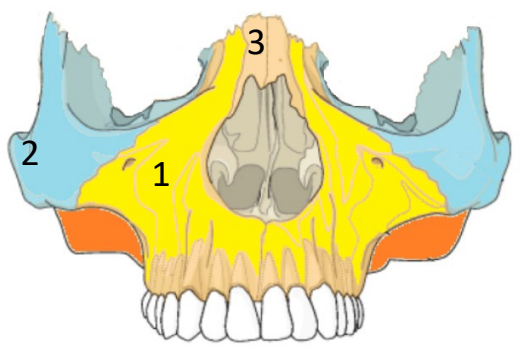

Gambar 1. Sepertiga tengah dari skeleton wajah 1) os maxilla, 2) os zigoma, 3) os nasal. ${ }^{4}$

Konsep buttress (Gambar 2) mewakili bidang dengan tulang yang lebih kuat yang mendukung unit fungsional wajah (otot, mata, oklusi gig, saluran pernafasan) dalam hubungan yang optimal dan menentukan bentuk wajah dengan memproyeksikan jaringan lunak diatasnya. ${ }^{5}$ Sistem buttress vertikal mempunyai 7 komponen yaitu (a) Di medial, sepasang nasomaksilaris, buttress mulai dari alveolus maksilaris anterior sampai ke apertura piriformis dan orbita medial, melewati os nasal dan lakrimal ke os frontal. (b) Pada lateral, sepasang zigomatikomaksilaris, buttress mulai dari alveolus maksilaris lateral ke maksilaris lateral, malar dari zigoma kemudian ke 
superior sepanjang rima orbita lateral ke os frontal. Buttress ini juga lateral meluas ke os temporal melalui arkus zigoma. (c) Sepasang pterigomaksilaris, buttress melewati pada posterior dari maksila ke pterigoid plate dari os spenoid. (d) Garis tengah tulang septum nasi, terdiri dari vomer dan perpendicular plate dari os etmoid, menghubungkan prosesus palatin dari maksila ke os frontal. ${ }^{6}$

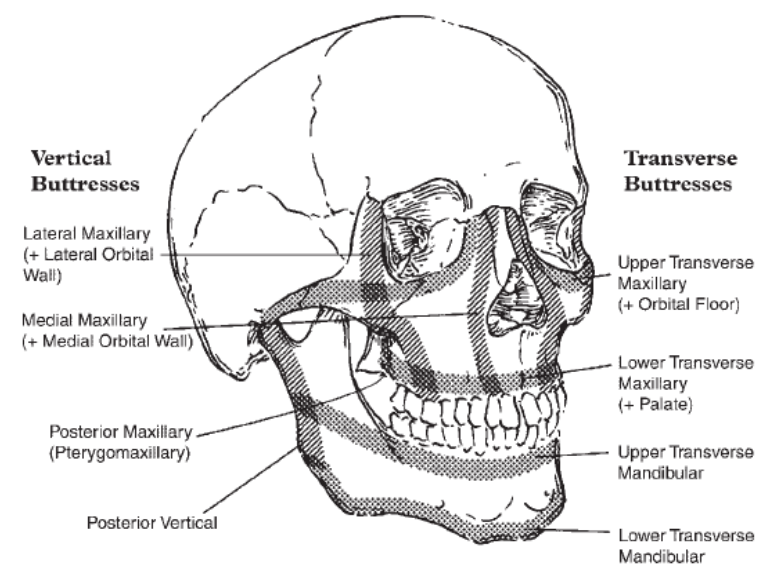

Gambar 2. Buttress vertikal dan horizontal ${ }^{5}$

Buttress horizontal, yaitu rima orbita superior, rima orbita inferior, maksiloalveolar dan palatum, prosesus zigoma os temporal, pinggir sayap os sfenoid dan pterigoid plate dari sfenoid. , $^{5,6}$

Klasifikasi

Alur fraktur yang diprediksi mengikuti tipe tertentu trauma. Tiga tipe yang dominan dapat dijelaskan yaitu fraktur Le Fort I (horizontal) yang dihasilkan dari trauma langsung pada bagian bawah rima alveolar maksilaris pada arah bawah. Fraktur mulai dari septum nasi ke rima pirifomis lateral, berjalan secara horizontal ke atas apeks gigi, menyeberang di bawah zigomaticomaksilaris junction, dan melewati pterigomaksilaris junction untuk sampai ke pterigoid plate. ${ }^{4,7}$

Fraktur Le Fort II (piramidal) hasil dari trauma pada mid maksila. ${ }^{6}$ Seperti fraktur yang mempunyai bentuk piramidal dan melewati nasal bridge atau di bawah sutura nasofrontal melalui prosesus frontal dari maksila, di bagian inferolateral melewati os lakrimal dan lantai serta rima orbita inferior atau dekat dengan foramen orbita inferior dan ke inferior melalui dinding anterior sinus maksila. Ini kemudian berjalan di bawah zigoma, ke fisura pterigomaksilaris dan melalui pterigoid plate. ${ }^{4,7}$

Le Fort III (transversa), juga dinamakan craniofasial disjunction, dapat mengikuti trauma pada nasal bridge atau maksila bagian atas. ${ }^{3}$ Ini hasil dari trauma langsung dari anterior ke sepertiga tengah wajah atau dari inferior trauma ke simfisis mandibular menjalar ke midface melalui segmen dentoalveolar mandibular. ${ }^{6}$ Fraktur ini mulai dari sutura nasofrontal dan frontomaksilaris dan meluas bagian posterior sepanjang dinding medial orbita melalui alur nasolakrimal dan os etmoid. Kemudian, fraktur berlanjut sepanjang fisura orbita inferior dan ke superolateral melalui dinding orbita lateral, melewati zigomaticofrontal junction dan arkus zigoma. Intra nasal, cabang dari fraktur meluas melalui dasar dari perpendicular plate dari etmoid, melalui vomer dan melalui penghubung dari pterigoid plate ke dasar dari sfenoid. 4,7

Fraktur midfasial atau panfasial dapat disertai dengan fraktur palataum. Fraktur palatum pertama kali dijelaskan oleh Rene Le Fort dalam makalahnya pada tahun 1901 pada fraktur maksila. Fraktur palatum ini jarang terjadi terlokalisir. Semua pasien dengan fraktur palatum memiliki gejala terkait fraktur Le Fort I pada penelitian tahun 1998 yang dilakukan oleh Hendrickson dkk. Selanjutnya,insidensi fraktur palatum pada pasien dengan fraktur Le Fort telah dilaporkan antara $8 \%$ dan $13,2 \% .^{8}$ Fraktur palatum diklasifikasikan berdasarkan lokasi fraktur. ${ }^{9-11}$ Chen dkk mengklasifikasikan fraktur palatum menjadi sagital, transversal dan kominuted. ${ }^{11}$ Salah satu hal yang fundamental dalam pentalaksanaan fraktur wajah yang sangat berat adalah perbaikan intraoperatif reduksi anatomi untuk memperoleh oklusi normal fraktur. ${ }^{6,7}$

Diagnosis

Pemeriksaan klinis selalu diperlukan, serta pemeriksaan computed tomography (CT) scan. Saat evaluasi klinis menunjukkan adanya fraktur, penting juga untuk melakukan pemeriksaan yang berhubungan dengan fungsi. ${ }^{7}$

1. Pemeriksaan penglihatan

Pemeriksaan yang teliti dan terarah pada orbita sebaiknya dilakukan pada pasien mengalami trauma pada maksilofasial. ${ }^{6}$ Penting juga untuk memeriksa pergerakan bola mata sebagai petunjuk adanya otot ekstraokular yang terperangkap (dan/atau trauma saraf). ${ }^{7}$

2. Pemeriksaan nervus kranial

Nervus kranial sebaiknya diperiksa, termasuk fungsi nervus yang mempengaruhi mata (nervus kranial II,III,IV dan VI), nervus trigeminal pada semua bagian dan terutama fungsi nervus wajah, tidak hanya untuk dokumentasi tetapi juga untuk kemungkinan dekompresi nervus jika diperlukan. ${ }^{7,12}$

3. Palpasi bimanual

Fraktur Le Fort biasanya dievaluasi dengan memeriksa pergerakan relatif dari os maksila dengan kranium. Arkus maksila anterior dipegang dan digoyang, dengan tangan yang lain di dahi. Jika ada pergerakan relatif arkus maksila dan maksila terhadap os frontal, fraktur Le Fort dapat dicurigai. Level pergerakan mungkin sulit dideteksi, tetapi CT scan akan memperkirakannya. ${ }^{7}$

\section{Radiografi}

Radiografi konvensional kurang ideal. Radiografi konvensional secara frekuen gagal untuk memberikan informasi yang detail mengenai sifat dan luas fraktur dasar tengkorak, trauma dinding orbita, fraktur pterigoid plate, fraktur sagital maksila dan prosesus condylar mandibular. CT scan adalah 
investigasi diagnostik utama dengan multiplanar dan rekonstruksi 3D. ${ }^{13} \mathrm{CT}$ scan memberikan manfaat untuk evaluasi tulang dan memberikan informasi detail tentang alur fraktur. CT scan juga memberikan informasi tentang jaringan lunak termasuk perluasan edema, adanya benda asing, hematom retrobulbar dan terjepitnya otot ekstraokular. ${ }^{4}$

\section{Penatalaksanaan}

Penatalaksanaan fraktur maksilofasial harus mengikuti panduan meliputi penatalaksanaan definitif awal, membuka secara luas segmen fraktur dan reposisi anatomi dengan fiksasi segmen fraktur pada semua potongan. ${ }^{14}$ Penatalaksanaan awal dari fraktur sepertiga tengah wajah meliputi prinsip umum dari penatalaksanaan trauma yaitu memastikan jalan nafas baik dan menjaganya, mengawasi perdarahan dan menelusuri dan menatalaksana trauma yang berhubungan (tulang belakang leher, trauma neurologi). ${ }^{15}$

Fraktur Le Fort I dapat secara adekuat diekspos melalui insisi sulkus ginggivobukal, fraktur Le Fort II memerlukan insisi pada kelopak mata bawah. Fraktur Le Fort III pendekatan memerlukan insisi koronal untuk mengekspos secara penuh nasofrontal, orbital medial dan regio zigoma. Untuk fraktur Le Fort I, miniplate ditempatkan pada masing-masing butrress nasomaxilaris dan zigomatikomaksilaris. Untuk Le Fort II, tambahan miniplate pada nasofrontal dan infraorbital. Untuk Le Fort III, stabilisasi pada artikulasio zigomatikomaksilaris. ${ }^{3}$ Fraktur dari anterior meluas ke fraktur palatum dapat dicapai melalui insisi ginggivobukal yang digunakan untuk mengekspos dan memperbaiki buttress vertikal. Tulang diatas gigi anterior lebih adekuat untuk penempatan miniplate dengan multiple screw. Harus berhati-hati untuk mencegah trauma pada akar gigi. Perluasan posterior fraktur palatum biasanya dapat direduksi dengan cara tertutup jika mukoperiosteum palatum intak. ${ }^{6}$

Teknik operasi fraktur palatum tipe sagital, dengan menggunakan archbar dan wire untuk menstabilkan alveolar ridge dan buttress maksila. ${ }^{9,11}$ Untuk fraktur palatum tipe transversal, setelah stabilisasi alveolar ridge dan buttress maksila dengan fiksasi intermaksila, dilakukan pemasangan miniplate dan screw pada alveolar ridge posterior. Untuk tipe kominuted, dilakukan dengan fiksasi intermaksila, dental splinting dan flap palatum untuk menutup defek palatum jika diperlukan. ${ }^{11}$

\section{LAPORAN KASUS}

Pasien laki-laki umur 19 tahun datang ke IGD RSUP Dr. M. Djamil Padang dengan keluhan utama hidung tersumbat sejak 4 sebelum masuk rumah sakit. Sebelumnya pasien sedang mengendarai motor, tibatiba ada motor lain berbelok ke kiri di depannya, motor pasien menabrak motor yang lain dan pasien terjatuh dengan muka membentur jalan. Pasien dirawat di rumah sakit umum daerah selama 2 hari dan dirujuk ke RSUP dr. M. Djamil Padang. Riwayat hidung berdarah setelah kejadian ada dan berhenti sendiri.
Terdapat bengkak dan nyeri pada hidung. Terdapat bengkak dan nyeri pada pipi kanan. Tidak ada rasa kebas pada pipi. Bengkak pada kelopak mata kanan, tidak terdapat penurunan penglihatan dan tidak ada nyeri menggerakkan bola mata. Susah membuka mulut tidak ada, nyeri membuka mulut ada. Tidak terdapat luka di tempat lain. Tidak terdapat riwayat penurunan kesadaran, muntah menyemprot dan kejang.

Pada pemeriksaan fisik, keadaan umum tampak sakit sedang, kesadaran composmentis, frekuensi nafas $20 \mathrm{x} /$ menit, frekuensi nadi $82 \mathrm{x} /$ menit, suhu $37,2^{\circ} \mathrm{C}$. Pemeriksaan fisik telinga dalam batas normal. Regio frontal edema, krepitasi, nyeri tekan tidak ada. Hidung luar defromitas ada, depressed. Tidak tampak edema, laserasi dan ekskoriasi. (Gambar 3) Kavum nasi dextra sempit, pendorongan dari lateral ke medial, konka inferior eutrofi, konka media sulit dinilai, septum deviasi tidak ada, sekret tidak ada. Clotting ada, darah mengalir tidak ada. Kavum nasi sinistra lapang, konka inferior eutrofi, konka media eutrofi, septum deviasi tidak ada, sekret tidak ada. Clotting dan darah mengalir tidak ada. Regio orbita dextra palpebra edema, infra orbita terdapat hematoma, terdapat perdarahan subkonjungtiva (Gambar 3). Regio orbita sinistra tidak terdapat kelainan. Regio zigoma tidak terdapat edema, nyeri tekan dan krepitasi.

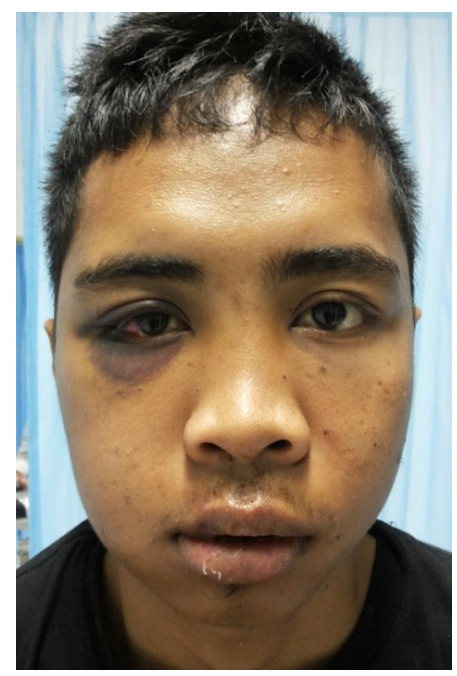

Gambar 3. Foto pasien

Regio maksila dextra dan sinistra, krepitasi tidak ada, depressed pada maksila sisi superior, nyeri tekan ada, edema tidak ada

Pemeriksaan palpasi bimanual, mobile. Regio mandibular edema, krepitasi dan nyeri tekan tidak ada. Pemeriksaan rongga mulut trismus tidak ada, maloklusi ada, tampak hematom pada palatum durum, ukuran $\pm 4 \times 0,1 \mathrm{~cm}$. Pemeriksaan tenggorok dalam batas normal.

Pasien sudah dilakukan pemeriksaan CT scan kepala dan 3D (Gambar 4) di Rumah Sakit asal rujukan. Tampak garis fraktur pada os nasal yang meluas ke os maksila. Dilakukan rontgen sinus 
paranasal posisi Waters (Gambar 5), tampak perselubungan pada sinus maksila dextra dan sinistra
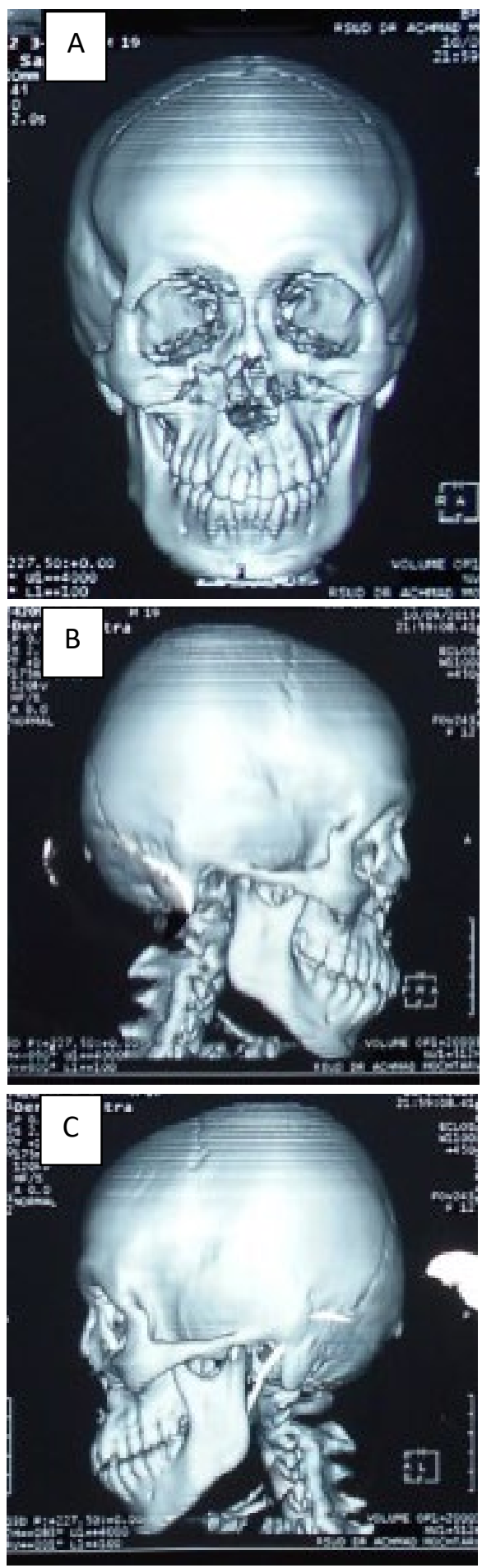

Gambar 4. CT Scan 3D tampak fraktur maksilofasial Le Fort I-II disertai fraktur palatoalveolar. A) tampak depan, B) tampak lateral kanan dan C) tampak lateral kiri.

Pasien didiagnosis dengan fraktur Le Fort I-II disertai fraktur palatoalveolar dan hematosinus maksila bilateral. Direncanakan dilakukan ORIF, pemasangan wire dan reposisi os nasal dalam anastesi umum. Dilakukan pemeriksaan laboratorium darah, hasil dalam batas normal.

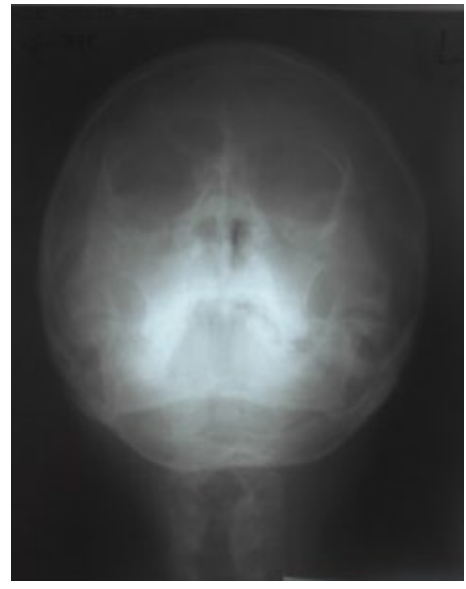

Gambar 5. Tampak perselubungan sinus maksila pada rontgen sinus paranasal posisi Waters

Pasien dilakukan operasi, pasien tidur terlentang di atas meja operasi dalam anastesi umum. Dilakukan tindakan aseptik dan antiseptik. Dilakukan infiltrasi pada daerah infraorbita dengan lidocaine: adrenalin 1:100.000. Dilakukan insisi subtarsal kanan dengan melakukan insisi $5 \mathrm{~mm}$ di bawah garis palpebra dengan Panjang $\pm 3 \mathrm{~cm}$. Muskulus orbikularis dipisahkan, diseksi dilakukan dari preseptal ke rima infraorbita di mana periostium dipisahkan dari os infra orbita. Tampak fraktur pada os infra orbita dan maksila. Dilakukan insisi subtarsal kiri dengan melakukan insisi $5 \mathrm{~mm}$ di bawah garis palpebra dengan panjang $\pm 3 \mathrm{~cm}$ tidak melewati tulang rim orbita. Muskulus orbikularis dipisahkan, diseksi dilakukan dari preseptal ke rima infraorbita dimana periostium dipisahkan dari os infra orbita. Tampak garis fraktur melalui foramen infra orbita dan maksila. Dilakukan reduksi dan pemasangan miniplate dan screw pada garis fraktur infra orbita dan maksilaris kiri dengan menggunakan miniplate 3 lubang dengan ketebalan 1,2 $\mathrm{mm}$ sebanyak 2 buah dan di fiksasi dengan screw autodrive dengan ukuran 2,0 x $6 \mathrm{~mm}$.

Infiltrasi submukosa sulkus ginggivobukal dengan adrenalin 1:100,000. Insisi ginggivobukal dilakukan $\pm 5 \mathrm{~mm}$ superior dari sulkus gingivobukal sepanjang $5 \mathrm{~cm}$. Insisi melalui mukosa, submukosa dan periosteum sampai ke struktur tulang. Dengan elevator periosteal, jaringan lunak pada subperiosteal didiseksi dan di elevasi. Os alveolar disisi kanan dan kiri fraktur di sejajarkan. Dilakukan pemasangan wire interdental pada insisivus kiri dan kanan. Miniplate dengan 4 lubang dengan ketebalan 1,2 mm diletakkan pada bagian medial tulang yang fraktur. Fiksasi dengan screw auto drive dengan ukuran 2,0 × $6 \mathrm{~mm}$ pada tiap lubang miniplate. Insisi sublabial ditutup dengan jahitan over and over continous dengan chromic catgut 3-0.

Evaluasi fraktur maksila pada sisi kanan melalui insisi subtarsal kanan. Tampak fraktur sudah tereduksi dengan pemasangan miniplate and screw pada maksila sisi kiri dan os alveolar. Dilakukan 
pemasangan miniplate 3 lubang dengan dengan ketebalan 1,2 $\mathrm{mm}$ dan screw autodrive ukuran 2,0 × $6 \mathrm{~mm}$ ditempatkan pada 2 lubang. Dilakukan reposisi os nasal dengan cunam Ash dan Walsham. Kemudian dilakukan evaluasi ulang terhadap garis fraktur pada tulang maksila, tampak fraktur telah tereduksi dengan baik. Pasang tampon anterior pada kedua kavum nasi untuk fiksasi interna dan gips untuk fiksasi eksterna. Luka insisi subsiliar kanan dan kiri dijahit dengan benang plain 3.0 untuk jahitan jaringan subkutis dan benang prolene 5.0 untuk jahitan subkutikuler. Dioleskan antibiotik topikal. Operasi selesai. Diagnosis post operasi adalah post ORIF atas indikasi fraktur Le Fort I-II disertai fraktur palatoalveolar sederhana. Pasien diberikan terapi cefoperazone $2 \times 1 \mathrm{gr}$, dexametason $3 \times 4 \mathrm{mg}$, ranitidine 2 × $50 \mathrm{mg}$. Kepala dielevasi $30-40^{\circ}$, diberikan diet makanan lunak.

Follow up hari pertama, nyeri pada kedua pipi ada, kebas pada kedua pipi tidak ada, darah merembes dari luka insisi tidak ada, nyeri buka mulut ada, susah buka mulut tidak ada Pada pemeriksaan fisik regio maksila kiri dan kanan edem (+) minimal, luka operasi baik, sekret (-). Pemeriksaan rongga mulut maloklusi (-). Dilakukan Rontgen cranium anteroposterior (gambar 6) untuk melihat posisi miniplate dan screw serta garis fraktur. Tampak terpasang fiksasi interna pada proyeksi dinding superior sinus maksila kanan dan kiri, alveolaris superior. Tidak tampak jelas gambaran garis fraktur, posisi IDW antara insisivus I kiri dan kanan terpasang baik.

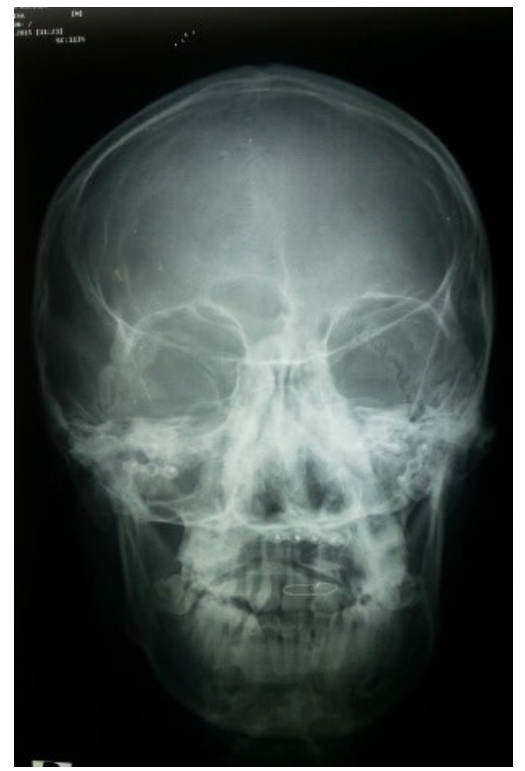

Gambar 6. Rontgen cranium 1 hari post operasi.

Follow up hari ke-3, nyeri pada kedua pipi ada dan sudah berkurang, kebas pada kedua pipi tidak ada, darah merembes dari luka insisi tidak ada, nyeri buka mulut ada, susah buka mulut tidak ada. Pada pemeriksaan fisik regio maksila kiri dan kanan tidak ada edem, luka operasi baik, sekret tidak ada.
Pemeriksaan rongga mulut tidak terdapat maloklusi, hematom di palatum durum masih tampak.

Dilakukan pembukaan tampon anterior. Evaluasi kavum nasi kanan dan kiri lapang, konka inferior eutrofi, konka media sulit dinilai, terdapat clotting, tidak terdapat darah mengalir. Pasien diperbolehkan pulang, diberi terapi clindamisin $3 \times 300$ $\mathrm{mg}$, asam mefenamant $3 \times 500 \mathrm{mg}$, pseudoefedrin HCL 60 mg + triprolidin HCL 2,5 mg $3 \times 1$ tablet.
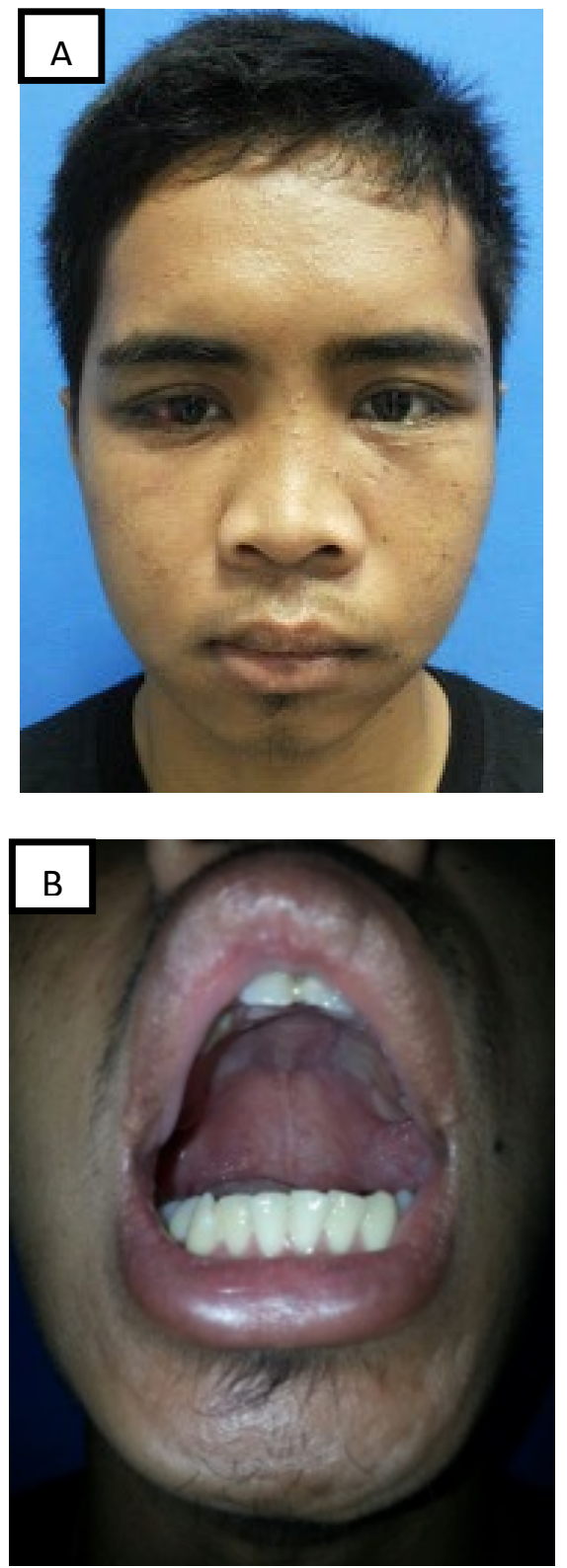

Gambar 7. A) Foto wajah pasien, B) Hematom di palatum durum sudah membaik, hari ke-14

\section{DISKUSI}

Telah dilaporkan satu kasus seorang laki-laki 19 tahun dengan diagnosis fraktur maksilofasial Le fort I-II dan fraktur palatalveolar. Berdasarkan penelitian selama 6 tahun oleh Campos dkk ${ }^{1}$ pada pasien yang mengalami fraktur Le Fort, pada pusat rumah sakit trauma Amerika Selatan didapatkan predominan lakilaki $90 \%$ dari 754 pasien. Dari penelitian Shankar dkk ${ }^{16}$ mengumpulkan data 2027 pasien dari berbagai pusat 
bedah maksilofasial di India didapatkan adanya predominan pria $(87.5 \%)$ dibandingkan wanita (12.4\%) dengan rasio $7: 1$ pada kejadian fraktur maksilofasial.

Pasien berumur 19 tahun, dengan penyebab fraktur maksilofasial adalah akibat kecelakaan lalu lintas. Shankar $\mathrm{dkk}^{16}$ melaporkan dari penelitian puncak insiden fraktur maksilofasial terjadi pada kelompok umur 21-30 tahun. Alasan yang memungkinkan untuk tingginya frekuensi trauma maksilofasial pada dekade ketiga kehidupan adalah fakta bahwa pada periode kehidupan tersebut lebih aktif berhubungan dengan olah raga, perkelahian, aktifitas kekerasan, industri dan menggunakan kendaraan dengan kecepatan tinggi. Sedangkan angka kejadian pada umur 11-20 tahun rendah karena rendahnya frekuensi aktivitas hal-hal seperti yang tersebut di atas pada kelompok umur ini. ${ }^{13}$

Penelitian oleh Campos $\mathrm{dkk}^{1}$ didapatkan penyebab fraktur fasial terbanyak (56\%) adalah kecelakaan lalu lintas. Penelitian oleh Chalya $\mathrm{dkk}^{17}$ pada 154 pasien juga menyatakan penyebab trauma maksilofasilal terbanyak adalah kecelakaan lalu lintas $(57,1 \%)$ diikuti dengan kekerasan $(16,2 \%)$ dan trauma akibat jatuh (14,3\%).

Pasien didiagnosis sebagai fraktur Le Fort I-II disertai fraktur palatoalveolar. Angka kejadian antara 3 tipe fraktur Le Fort bervariasi. Penelitian Campos dkk ${ }^{1}$ pada 754 pasien dengan fraktur Le Fort didapatkan fraktur Le Fort terbanyak adalah fraktur Le Fort II sebanyak $52 \%$, diikuti dengan Le Fort I $22 \%$, tipe Le Fort yang berhubungan dengan fraktur lain $20 \%$ and Le Fort III 6 \%. Penelitian Ahmed dkk ${ }^{13}$ dari 83 pasien dengan fraktur Le fort, 27 pasien diklasifikasikan sebagai fraktur Le Fort I, 33 pasien fraktur Le Fort II dan 28 pasien fraktur Le Fort III. Penelitian oleh Scheyerer dkk $^{14}$ dari 67 pasien, 25\% mengalami fraktur Le Fort dengan fraktur Le Fort III merupakan tipe yang paling sering.

Telah dilakukan pemeriksaan radiologi dengan rekonstruksi 3D. Penelitian oleh Porosito dkk $^{15}$ dari 67 pasien didapatkan sensitivitas tertinggi rekonstruksi 3D didapatkan pada fraktur os maksila, arkus zigoma, os nasal dan mandibula. Rekonstruksi 3D kurang berguna untuk evaluasi pada fraktur dinding medial orbita dan dinding medial sinus maksila. ${ }^{15,18}$

Pasien dilakukan tindakan ORIF menggunakan miniplate dan screw untuk fraktur Le Fort dan ORIF serta pemasangan wire untuk fraktur palatoalveolar. Open Reduction Intenal Fixation merupakan standar emas dalam penatalaksanaan fraktur maksilofasial. Hal-hal yang ikut berpengaruh dalam pemilihan penatalaksanaan fraktur maksilofasial tergantung dari banyak faktor seperti biaya, keinginan pasien, kemungkinan dilakukannya pada rumah sakit, keputusan dokter dan keterampilan. ${ }^{17}$ Ahmed dkk $^{13}$ dari 83 pasien dengan fraktur Le Fort, 33 pasien ditatalaksana dengan ORIF menggunakan miniplate dengan ketebalan $1,5 \mathrm{~mm}$ dan 50 pasien (61\%) ditatalaksana dengan konservatif menggunakan archbars dan sebagai tambahan menggunakan wire. Penatalaksanaan konservatif dilakukan pada keadaan fraktur stabil, undisplaced atau asimtomatik, tanpa gangguan oklusal atau masalah fungsi lainnya. ${ }^{13,16}$ Pada penelitian oleh Shankar dkk ${ }^{16}$, dari 2027 pasien dengan fraktur maksilofasial selama 5 tahun, 50,8\% pasien di tatalaksana dengan metode terbuka dan $49,2 \%$ dengan metode tertutup.

Palatum durum adalah penjalaran posterior dari butrress transversal bawah dari maksila. Fraktur palatum akan memperluas arkus dentomaksilaris dan menyebabkan maloklusi. ${ }^{18}$ Fraktur palatum jarang terjadi dan hanya beberapa kasus yang telah dilaporkan pada beberapa literatur. ${ }^{19}$

Penelitian oleh Chen $\mathrm{dkk}^{11}$, dari 162 review kasus dalam 10 tahun, insiden fraktur palatum dengan fraktur Le fort adalah 46,4\%. Fraktur palatum tipe I (tipe sagital) adalah pola fraktur yang paling umum (91\%) dari kasus dimana subtipe paramedian adalah yang paling sering. Fraktur palatum ditatalaksana dengan berbagai teknik termasuk fiksasi intermaksila, fiksasi dengan wire dan fikasasi menggunakan miniplate. ${ }^{19,20}$ Semua penatalaksanaan bertujuan untuk mengembalikan posisi palatum dan memperoleh kembali fungsi oklusi. ${ }^{19}$

\section{SIMPULAN}

Fraktur sepertiga tengah wajah biasanya diakibatkan oleh berbagai trauma, dapat terjadi tersendiri maupun bersamaan dengan fraktur lain.

Open reduction internal fixation (ORIF) dengan miniplate dan screw telah menjadi pilihan pada fraktur maksilofasial karena lebih stabil dalam hal fungsi dan fiksasi tulang yang lebih baik.

Berdasarkan indikasi, fiksasi intermaksila, palatum splint, dan wire dapat digunakan secara tersendiri atau kombinasi untuk penatalaksanaan fraktur palatoalveolar.

\section{DAFTAR PUSTAKA}

1. Campos $\mathrm{GH}$, Leandro L, Yamamoto $\mathrm{MK}$, Júnior RC, Luz JGC. Trends in le fort fractures at a south american trauma care center: characteristics and management. J Maxillofac Oral Surg. 2015; 15(1):32-7.

2. Ebenezer V, Ramalingam B. Microplate osteosynthesis in middle third fractures of the face. Univers J Med Dent. 2012; 1(6):70-5.

3. Cole H. Facial fractures: principles of evaluation and repair. In: Head and Neck Reconstruction. Edinburg: Elsevier; 2009. p.153-66.

4. Aktop, Gonul, Satilmis, Garip, Goker. Management of midfacial fractures. In: A textbook of advanced oral and maxillofacial surgery; 2013. p.415-45.

5. Hopper RA, Salemy S, Sze RW. Diagnosis of midface fractures with $\mathrm{CT}$ : what the surgeon needs to know. RadioGraphics. 2006; 26(3):78393. 
6. Stack R. Maxillary and periorbital fracture. In: Head and neck surgery otolaryngology. 4th ed. Philadelphia: Lippincot Williams and Wilkins; 2006. p.994-1014.

7. Kellman R, Morehead J. Midfacial trauma. In: Resident manual of trauma to the face, head and neck. 1st ed. AAO-HNS Foundation; 2012. p.7499.

8. Hoppe IC, Halsey JN, Ciminello FS, Lee ES, Granick MS. A single - center review of palatal fractures : etiology, patterns, concomitant injuries , and management. E Plasty. 2017; 17:180-7.

9. Karaci S, Köse R. A case of maxillo palatal mid face fracture. Ann Otolaryngol Rhinol. 2015; 2(7):1-3.

10. Park S, Ock J. A new classification of palatal fracture and an algorithm to establish a treatment plan. Plast Reconstr Surg. 2001; 107(7):166976.

11. Chen $\mathrm{CH}$, Wang TY, Tsay PK, Lai J Bin, Chen CT, Liao HT, et al. A 162-case review of palatal fracture: management strategy from a 10-year experience. Plast Reconstr Surg. 2008; 121(6):2065-73.

12. Stack BC, Ruggiero FP. Midface fracture. In: Bailey BJ, Johnson JT, Newlands SD. Bailey's head and neck surgery Otolaryngology. 5th ed. Philadelphia: Wolters Kluwer Lippincot Williams and Wilkins; 2014. p.1209-24.

13. Ahmed A, Ahmed W, Bukhari S, Janjua O, Luqman U, Qayyum M. The maxillofacial trauma management trends at armed forces institute of dentistry, rawalpindi. Pakistan oral Dent J. 2012; 32(2):191-5.

14. Scheyerer MJ, Döring $R$, Fuchs $N$, Metzler $P$, Sprengel K, Werner CML, et al. Maxillofacial injuries in severely injured patients. J Trauma Manag Outcomes. 2015; 9(1):4.

15. Porosito J, Skrzelewski S, Sraga W, Borowiak H, Jackowska Z, Kluczewska E. CT imaging of facial trauma. Role of different types of reconstruction. Part I - Bones. Polish J Radiol. 2011; 76(1):4151.

16. Shankar A, Shankar V, Hegde N, Sharma, Prasad R. The pattern of the maxillofacial fractures - A multicentre retrospective study. J Cranio-Maxillofacial Surg. 2012; 40:675-9.

17. Chalya PL, Mchembe M, Mabula JB, Kanumba ES, Gilyoma JM. Etiological spectrum, injury characteristics and treatment outcome of maxillofacial injuries in a Tanzanian teaching hospital. J Trauma Manag Outcomes. 2011; 5(7):1-6.

18. Kaur J, Chopra R. Three dimensional CT reconstruction for the evaluation and surgical planning of mid face fractures: A 100 case study. J Maxillofac Oral Surg. 2010; 9(4):323-8.

19. Cunningham K. Early assesment and treatment planning of the maxillofacial trauma patient. In: Oral and maxillofacial trauma. St. Louis: Elsevier;
2013. p.220-31.

20. Wells MD, Sichi S, Sengezer M. Sagittal fractures of palate: a new method of treatment. Can J Plast Surg. 1995; 3(2). 